\title{
Pengaruh Benih Padi (Oryza sativa L.) Bersubsidi terhadap Produksi dan Pendapatan Petani Padi Sawah
}

\author{
Effect of Subsidized Paddy Seeds (Oryza sativa L.) against Production and Farmer Income
}

\author{
Azka Radiethya Riefqi, Memen Surahman", dan Hastuti \\ Departemen Agronomi dan Hortikultura, Fakultas Pertanian, Institut Pertanian Bogor \\ (Bogor Agricultural University), Jl. Meranti, Kampus IPB Darmaga, Bogor 16680, Indonesia \\ Telp.\&Faks. 62-251-8629353 e-mail agronipb@indo.net.id \\ *Penulis untuk korespondensi : memensurahman@yahoo.co.id \\ Disetujui 16 Januari 2017/Published online 24 Januari 2017
}

\begin{abstract}
Paddy is the main commodity which continoue to experience increased demand due to population growth, so that the right policies needed in order to increase national production and farming activities can be beneficial for farmers. This research aimed to compare the production and income between farmers who use subsidized paddy seed and farmers who used unsubsidized paddy seed. This research was conducted in the District Tenjolaya for the respondents who use subsidized paddy seed and District Dramaga for the respondents who use unsubsidized paddy seed. The research was conducted from February to April 2016. The number of survey respondents are as many as 40 people, divided into 20 respondents users of subsidized paddy seed and 20 respondents who used unsubsidized paddy seed through in-depth interviews with a purposive sampling method. The results showed that farmers used subsidized paddy seed have higher levels on productivity and income than the farmers who used unsubsidized paddy seed. It is influenced by the use of production inputs were more dominant in organic fertilizers and certified seeds
\end{abstract}

Keywords : farming activity, production, revenue, seed, subsidies

\begin{abstract}
ABSTRAK
Padi merupakan komoditas utama yang terus mengalami peningkatan permintaan seiring dengan pertambahan jumlah penduduk, sehingga dibutuhkan kebijakan yang tepat agar produksi nasional meningkat dan kegiatan usahatani dapat menguntungkan petani. Penelitian ini bertujuan untuk mengetahui perbandingan produksi dan pendapatan petani antara pengguna benih padi bersubsidi dan tidak bersubsidi. Penelitian ini dilaksanakan di Kabupaten Bogor, yakni: Kecamatan Tenjolaya untuk responden petani pengguna benih padi bersubsidi dan Kecamatan Dramaga untuk responden petani yang menggunakan benih padi tidak bersubsidi. Penelitian dilaksanakan dari Februari hingga April 2016. Jumlah responden penelitian sebanyak 40 orang, yang terbagi menjadi 20 responden pengguna benih padi bersubsidi dan 20 responden yang menggunakan benih padi tidak bersubsidi melalui in depth interview dengan metode purposive sampling. Hasil penelitian menunjukkan bahwa petani yang menggunakan benih padi bersubsidi memiliki tingkat produktivitas dan pendapatan yang lebih tinggi dibandingkan dengan petani yang menggunakan benih padi tidak bersubsidi. Hal tersebut dipengaruhi oleh penggunaan input produksi yang lebih dominan pada pupuk organik dan benih bersertifikat.
\end{abstract}

Kata kunci: benih, pendapatan, produksi, subsidi, usahatani 


\section{PENDAHULUAN}

Padi (Oryza sativa L.) merupakan komoditas unggulan utama tanaman pangan yang pengembangannya diarahkan pada daerah sentra produksi padi. Peningkatan produktivitas padi terutama padi sawah perlu dilakukan agar produksi padi nasional yang dihasilkan juga meningkat. Hal ini dikarenakan kebutuhan terhadap beras terus meningkat sesuai dengan perkembangan penduduk sebesar $1.9 \%$ per tahun (Mahmud et al., 2010). Pendapat ini didukung oleh Riyanto et al. (2013) bahwa sekitar 95\% penduduk Indonesia masih mengandalkan beras sebagai komoditas pangan utama dan dari tahun ke tahun kebutuhan beras di Indonesia terus mengalami peningkatan seiring bertambahnya jumlah penduduk. IRRI (2001) menambahkan bahwa sampai saat ini kebutuhan kalori dan protein masih dipenuhi dari beras, yaitu masingmasing sekitar $56 \%$ dan $46 \%$.

$$
\text { Badan Pusat Statistik }
$$

menunjukkan bahwa produksi padi nasional tahun 2014 (ASEM) sebanyak 70.83 juta ton gabah kering giling (GKG) mengalami penurunan sebesar 0.45 juta ton $(0.63 \%)$ dibandingkan tahun 2013. Penurunan produksi diperkirakan terjadi karena penurunan luas panen seluas $41.61 \mathrm{ribu}$ hektar $(0.30 \%)$ dan penurunan produktivitas sebesar $0,17 \mathrm{ku} \mathrm{ha}^{-1}(0.33 \%)$. Jumlah penduduk Indonesia meningkat pada periode 2000-2006 dengan laju pertumbuhan $1.36 \%$ per tahun sementara konsumsi beras diperkirakan $137 \mathrm{~kg}$ per kapita. Apabila laju pertumbuhan penduduk diasumsikan menurun $0.03 \%$ per tahun, maka konsumsi beras pada 2010, 2015, dan 2020 diproyeksikan berturut-turut sebesar 32.13 juta ton, 34.12 juta ton, dan 35.97 juta ton.

Padi atau beras memiliki dampak terhadap stabilitas ekonomi dan politik. Widiarsih (2013) berpendapat bahwa apabila terjadi fluktuasi pada beras yang berkaitan dengan ketersediaan pasokan maupun peningkatan harga, maka akan berdampak bagi stabilitas politik. Hal ini menunjukkan ketersediaan dan kestabilan harga beras merupakan salah satu kunci bagi tercapainya stabilitas nasional, terutama stabilitas ekonomi.

Berdasarkan hal tersebut perlu dilaksanakannya suatu kebijakan yang fungsinya untuk menjaga stabilitas harga dan ketersediaan padi. Kebijakan-kebijakan yang dapat diambil untuk mengembangkan sektor pertanian tidak hanya insentif berupa output, namun juga berupa input produksinya (Rachman et al., 2004). Menurut Ellis (1992) kebijakan variabel input memiliki tiga dimensi, yaitu tingkat harga dari variabel input, sistem pengiriman dari variabel, serta ketersediaan informasi untuk petani, namun pada beberapa kasus terdapat dimensi keempat yaitu kredit untuk pembelian variabel input.

Kebijakan insentif input produksi yang telah dilakukan pemerintah adalah subsidi benih yang termasuk kedalam kebijakan input pada tingkat harga yang diharapkan. Program subsidi benih diharapkan dapat memberikan benih dengan harga murah namun memiliki kualitas yang baik (bermutu dan bersertifikat) kepada petani. Akan tetapi, fakta di lapangan menunjukkan hal sebaliknya. Kariyasa (2007) berpendapat bahwa kebijakan subsidi benih lewat produsen benih selama ini kurang efektif. Hal ini terlihat dari masih banyaknya petani belum menggunakan benih berlabel karena harganya yang relatif mahal dan kualitas benih yang dihasilkan produsen belum sesuai harapan. Adanya program subsidi benih diharapkan dapat meningkatkan produktivitas dan tingkat pendapatan petani serta penggunaan input produksi yang lebih efisien.

\section{METODE PENELITIAN}

Penelitian ini dilaksanakan di Kabupaten Bogor, yakni: Desa Cibitung, Kecamatan Tenjolaya untuk responden yang menggunakan benih padi bersubsidi dan Desa Ciherang, Kecamatan Dramaga untuk responden yang menggunakan benih padi tidak bersubsidi. Setiap lokasi diambil 20 responden sebagai sample untuk penelitian (20 responden pengguna benih padi bersubsidi dan 20 responden pengguna benih padi tidak bersubsidi). Pemilihan lokasi didasarkan pada keterjangkauan lokasi penelitian dan rekomendasi dari Balai Penyuluhan Pertanian, Perikanan, dan Kehutanan (BP3K) setempat. Penelitian berlangsung dari Februari hingga April 2016.

Metode pengumpulan data yang digunakan pada penelitian ini adalah observasi langsung ke lapangan dengan melakukan wawancara mendalam (in depth interview) menggunakan daftar pertanyaan (kuesioner). Pertanyaan ditujukan kepada masing-masing kelompok petani (pengguna benih padi bersubsidi maupun pengguna benih padi tidak bersubsidi) yang didampingi oleh ketua kelompok tani. Data yang dihasilkan berupa data primer (hasil wawancara) dan data sekunder. Pengukuran kesuburan tanah petani dilakukan dengan alat perangkat uji tanah sawah (PUTS) yang bertujuan untuk mengetahui nilai $\mathrm{pH}$, kandungan unsur $\mathrm{N}$, unsur $\mathrm{P}$, dan unsur K. Pengambilan contoh untuk mengetahui status hara (kesuburan tanah) menggunakan sistem composite sample, yaitu pencampuran contoh yang diambil dari areal yang 
dikehendaki (Rosmarkam dan Yuwono, 2002). Penentuan karakteristik benih dan teknologi budidaya dilakukan dengan membandingkan karakteristik benih bersubsidi dengan yang tidak bersubsidi berdasarkan data hasil kuesioner yang didapat. Data yang dibandingkan meliputi varietas, kelas, dan mutu benih. Teknologi budidaya juga dibandingkan dengan hasil akhir berupa hasil produksi berdasarkan input teknologi yang digunakan. Analisis data terbagi menjadi dua bagian, yakni : analisis faktor produksi dan analisis pendapatan. Analisis faktor-faktor yang memengaruhi produksi padi dianalisis menggunakan persamaan regresi berganda dan uji signifikansi dengan uji t-hitung, f-hitung, dan $\mathrm{R}^{2}$. Data yang didapat diolah dengan menggunakan metode Ordinary Least Square (OLS) dan diuji dengan uji kriteria ekonometrika (normalitas, heterokedastisitas, dan multikolinieritas) sehingga didapatkan fungsi produksi Cobb-Douglas. Analisis faktor-faktor produksi diolah menggunakan software eviews 8.1. Analisis pendapatan petani dilakukan dengan menganalisis perbedaan tingkat penerimaan, biaya, dan pendapatan antara petani yang menggunakan benih padi bersubsidi dan menggunakan benih padi tidak bersubsidi. Analisis pendapatan juga dianalisis berdasarkan perhitungan $\mathrm{R} / \mathrm{C}$ ratio yang diolah dengan menggunakan software Microsoft excel 2010.

\section{HASIL DAN PEMBAHASAN}

\section{Kondisi Umum}

Penelitian dilaksanakan di Kabupaten Bogor pada dua desa yang berbeda, yaitu Desa Ciherang, Kecamatan Dramaga untuk responden yang menggunakan benih padi tidak bersubsidi dan Desa Cibitung, Kecamatan Tenjolaya untuk responden yang menggunakan benih padi bersubsidi. Desa Ciherang merupakan bagian dari Kecamatan Dramaga yang memiliki luas sebesar 251.57 ha dengan ketinggian sekitar 196 mdpl. Suhu udara rata-rata $25^{\circ} \mathrm{C}-32^{\circ} \mathrm{C}$. Desa Ciherang memiliki areal persawahan seluas 151 ha dan ladaDng seluas 20.34 ha (Data Monografi, 2015). Hama dan penyakit yang sering menyerang pertanaman padi di desa Ciherang adalah tungro, penggerek batang, dan wereng hijau. Lokasi penelitian kedua adalah Desa Cibitung Tengah yang merupakan bagian dari Kecamatan Tenjolaya, Desa Cibitung Tengah memiliki luas sebesar 310.085 ha dengan ketinggian sekitar 1
350 mdpl. Suhu rata-rata Desa Cibitung Tengah adalah $27.5^{\circ} \mathrm{C}$ dengan elevasi lahan antara $25^{\circ}$ sampai $35^{\circ}$ dan memiliki areal persawahan seluas 25.235 ha (Profil Desa, 2015). Hama dan penyakit yang sering menyerang pertanaman padi adalah tungro, penggerek batang, wereng hijau, dan walang sangit.

\section{Perbandingan Produksi Benih Padi Bersubsidi dan Benih Padi Tidak Bersubsidi}

Hasil produksi petani yang menggunakan benih padi bersubsidi lebih tinggi dibandingkan dengan petani yang menggunakan benih padi tidak bersubsidi. Harga jual output kedua kategori petani tidak menunjukkan perbedaan yang cukup besar, meskipun harga jual tertinggi dimiliki oleh petani yang menggunakan benih padi tidak bersubsidi. Data tersebut dapat dilihat di Tabel 1.

Tabel 1. Rata rata produksi dan harga output padi berdasarkan penggunaan benih padi

\begin{tabular}{cccc}
\hline No & $\begin{array}{c}\text { Penggunaan Benih } \\
\text { Padi }\end{array}$ & $\begin{array}{c}\text { Produksi } \\
\left(\mathrm{kg} \mathrm{ha}^{-1}\right)\end{array}$ & $\begin{array}{c}\text { Harga } \\
\text { Output } \\
\left(\mathrm{Rp} \mathrm{kg}^{-1}\right)\end{array}$ \\
\hline 1 & Subsidi & 7318.35 & 3420.00 \\
2 & Non Subsidi & 5913.65 & 3575.00 \\
\hline
\end{tabular}

Sumber: Data Primer Diolah, 2016

Perbedaan produksi yang dihasilkan oleh petani disebabkan karakteristik benih yang digunakan dan sistem penanaman, meskipun hama dan penyakit tanaman serta ketersediaan irigasi di kedua lokasi relatif tidak berbeda. Varietas benih yang digunakan oleh petani yang menggunakan benih padi tidak bersubsidi telah sesuai anjuran, berbeda dengan benih yang digunakan petani pengguna benih padi bersubsidi yang cenderung tidak sesuai dalam hal ketinggian lokasi.

Hasil produksi yang rendah pada petani pengguna benih tidak bersubsidi disebabkan karena sebagian petani melakukan kegiatan budidaya dengan menggunakan benih yang tidak memiliki kelas serta tidak berlabel. Benih tersebut didapatkan petani dari hasil penanaman sebelumnya yang tidak ditujukan sebagai benih di awal penanaman. Petani pengguna benih padi bersubsidi memiliki sistem tanam yang lebih baik, yakni sistem jajar legowo yang mampu menghasilkan output produksi lebih tinggi karena adanya rekayasa efek pinggir tanaman. 
Tabel 2. Deskripsi benih, hama dan penyakit, dan irigasi berdasarkan penggunaan benih padi

\begin{tabular}{rlll}
\hline \multirow{2}{*}{ No } & \multicolumn{2}{c}{ Jenis } & \multicolumn{2}{c}{ Penggunaan Benih Padi } \\
\cline { 3 - 4 } & & \multicolumn{1}{c}{ Non Subsidi } \\
\hline 1 & Varietas & Mekongga & Inpari 13, Inpari 16, Ciherang \\
2 & Kelas Benih & ES & ES, tidak berkelas \\
3 & Label Benih & Biru & Biru, tidak berlabel \\
4 & Hama dan Penyakit & Tungro, penggerek batang, walang & Tungro, penggerek batang, wereng \\
& Tanaman & sangit, hawar daun & hijau \\
5 & Irigasi & Ada & Ada \\
6 & Sistem Tanam & Jajar legowo $2: 1(40 \times 20 \times 12,5) \mathrm{cm}$ & Konvensional $(20 \times 20) \mathrm{cm}$ \\
\hline
\end{tabular}

Tingkat produksi output yang lebih tinggi pada petani pengguna benih padi bersubsidi dapat dipengaruhi oleh beberapa hal, diantaranya penggunaan pupuk organik dengan volume lebih tinggi serta penggunaan pupuk kimia yang lebih rendah. Penggunaan pupuk organik sebagai pengganti pupuk kimia dapat menjaga ketersediaan unsur hara dan kesuburan tanah, sehingga akan berdampak pada tingkat produksi yang lebih tinggi, hal ini tertera pada Tabel 3. Pupuk organik yang digunakan petani adalah jerami hasil sisa pertanaman padi. BPTP Kaltim (2011) berpendapat bahwa pemanfaatan jerami dalam kaitannya untuk menyediakan hara dan bahan organik tanah adalah dengan merombaknya menjadi kompos. Hasil analisa laboratorium BPTP Kaltim menunjukkan bahwa kompos jerami memiliki kandungan hara setara dengan $41.2 \mathrm{~kg}$ urea dan $4.5 \mathrm{~kg}$ SP-36 per ton kompos. Jumlah hara ini kurang lebih dapat memenuhi lebih dari setengah kebutuhan pupuk kimia petani.

Penggunaan pupuk kimia yang tinggi khususnya pupuk urea dapat menjadi salah satu alasan rendahnya tingkat produksi padi pada petani yang menggunakan benih padi tidak bersubsidi. Wahid (2003) menjelaskan dalam penelitiannya bahwa berdasarkan anjuran, N cukup diberikan sebanyak $90-120 \mathrm{~kg} \mathrm{ha}^{-1}$ atau setara dengan 200-260 $\mathrm{kg} \mathrm{ha}^{-1}$ pupuk urea, sedangkan pada penelitian menunjukkan bahwa petani yang menggunakan benih padi tidak bersubssidi menggunakan pupuk urea sebanyak $453.83 \mathrm{~kg} \mathrm{ha}^{-1}$ pada satu musim tanam. Hal ini yang menjadi salah satu penyebab penurunan produksi padi.

Tabel 3. Rata-rata input produksi berdasarkan penggunaan benih padi

\begin{tabular}{|c|c|c|c|c|c|c|}
\hline \multirow[b]{2}{*}{ No } & \multirow[b]{2}{*}{ Input Produksi } & \multirow[b]{2}{*}{ Satuan } & \multicolumn{2}{|c|}{ Subsidi } & \multicolumn{2}{|c|}{ Non Subsidi } \\
\hline & & & Jumlah ha ${ }^{-1}$ & $\begin{array}{c}\text { Harga } \\
\text { Satuan } \\
(\mathrm{Rp})\end{array}$ & Jumlah ha ${ }^{-1}$ & $\begin{array}{c}\text { Harga } \\
\text { Satuan } \\
\text { (Rp) }\end{array}$ \\
\hline 1 & Benih & $\mathrm{kg}$ & 36.20 & 3320.00 & 65.85 & 8900.00 \\
\hline 2 & Pupuk Kompos & $\mathrm{kg}$ & 759.09 & 1000.00 & 416.67 & 1200.00 \\
\hline 3 & Pupuk Kandang & $\mathrm{kg}$ & 800.00 & 500.00 & 759.26 & 207.44 \\
\hline 4 & Pupuk Urea & $\mathrm{kg}$ & 158.33 & 1950.00 & 453.83 & 2555.55 \\
\hline 5 & Pupuk TSP & $\mathrm{kg}$ & 195.24 & 2171.43 & 186.33 & 2906.25 \\
\hline 6 & Pupuk KCl & $\mathrm{kg}$ & 150.00 & 2300.00 & 200.00 & 3000.00 \\
\hline 7 & Pupuk Phonska & $\mathrm{kg}$ & 221.57 & 2358.82 & 850.00 & 1089.00 \\
\hline 8 & $\begin{array}{l}\text { Pupuk NPK } \\
\text { Kujang }\end{array}$ & $\mathrm{kg}$ & 100.00 & 2500.00 & 0.00 & 0.00 \\
\hline 9 & Pestisida & $\mathrm{g}$ & 202.28 & 291.43 & 0.00 & 0.00 \\
\hline 10 & Pestisida & $\mathrm{ml}$ & 930.83 & 349.75 & 746.31 & 125.71 \\
\hline 11 & $\begin{array}{l}\text { Tenaga Kerja } \\
\text { Pria Dalam } \\
\text { Keluarga }\end{array}$ & HOK & 25.13 & 48000.00 & 52.83 & 65000.00 \\
\hline 12 & $\begin{array}{l}\text { Tenaga Kerja } \\
\text { Wanita Dalam } \\
\text { Keluarga }\end{array}$ & $\mathrm{HOK}$ & 1.84 & 24000.00 & 57.25 & 25000.00 \\
\hline 13 & $\begin{array}{l}\text { Tenaga Kerja } \\
\text { Pria Luar } \\
\text { Keluarga }\end{array}$ & $\mathrm{HOK}$ & 39.82 & 48000.00 & 62.12 & 65000.00 \\
\hline 14 & $\begin{array}{l}\text { Tenaga Kerja } \\
\text { Wanita Luar } \\
\text { Keluarga }\end{array}$ & $\mathrm{HOK}$ & 53.62 & 24000.00 & 83.15 & 25000.00 \\
\hline
\end{tabular}


Jumlah penggunaan benih yang berbeda antara kedua kategori petani disebabkan oleh praktik budidaya yang dilakukan oleh petani. Petani yang menggunakan benih padi bersubsidi rata-rata menanam benih padi sebanyak dua sampai tiga benih per lubang tanam, sedangkan petani yang menggunakan benih padi tidak bersubsidi menanam sebanyak tiga smpai lima benih per lubang tanam. Jumlah benih per lubang tanam yang tinggi pada petani pengguna benih padi tidak bersubsidi disebabkan oleh kekhawatiran petani akan serangan hama dan penyakit yang akan berdampak pada turunnya hasil output produksi. Data menunjukkan bahwa area pertanaman kedua kategori petani memiliki jenis hama dan penyakit tanaman yang relatif sama, namun petani pengguna benih padi bersubsidi mampu lebih efisien dalam penggunaan benih padi.

\section{Perbandingan Pendapatan Petani Pengguna Benih Padi Bersubsidi dan Benih Padi Tidak Bersubsidi}

Petani yang menggunakan benih padi bersubsidi mendapatkan penerimaan yang lebih tinggi dibandingkan petani yang tidak menggunakan benih padi bersubsidi dalam satuan ha pada setiap musim tanam, hal ini dapat dilihat pada Tabel 4. Perbedaan jumlah penerimaan yang didapatkan oleh dua kelompok dipengaruhi oleh jumlah output yang dihasilkan dan harga penjualan output tersebut. Petani yang menggunakan benih padi bersubsidi mampu menghasilkan output yang lebih tinggi dibandingkan petani yang menggunakan benih padi tidak bersubsidi, namun petani yang menggunakan benih padi tidak bersubsidi menjual hasil outputnya dengan harga yang lebih tinggi dibandingkan kelompok petani yang menggunakan benih padi bersubsidi.

Tabel 4. Jumlah penerimaan pekerjaan sampingan petani

\begin{tabular}{clc}
\hline No & $\begin{array}{l}\text { Penggunaan } \\
\text { Benih Padi }\end{array}$ & Penerimaan (Rp) \\
\hline 1 & Subsidi & 1856250.00 \\
2 & Non Subsidi & 1519230.77 \\
\hline
\end{tabular}

Perbedaan pendapatan kedua kategori petani disebabkan oleh perbedaan pengeluaran biaya yang dikeluarkan untuk penggunaan input (biaya tunai dan biaya non tunai). Petani penggguna benih padi bersubsidi mengeluarkan biaya tunai yang lebih rendah karena jumlah input produksi yang digunakan juga lebih rendah. Petani pengguna benih bersubsidi cenderung menggunakan tenaga kerja, benih, serta pupuk kimia yang lebih rendah dibandingkan petani yang menggunakan benih padi tidak bersubsidi. Pemakaian input produksi yang lebih tinggi adalah input berupa pupuk organik, pupuk NPK, serta pestisida, data tertera pada Tabel 3. Harga pembelian input yang lebih rendah pada petani pengguna benih padi bersubsidi (benih, pupuk kompos, pupuk kimia, penyewaan alat pengolah lahan, dan tenaga kerja) juga memengaruhi tingginya pendapatan. Biaya non tunai tertinggi dikeluarkan oleh petani pengguna benih tidak bersubsidi, hal tersebut mengindikasikan bahwa kategori petani tersebut memiliki kepemilikan peralatan pertanian yang lebih beragam dibandingkan kategori petani lainnya. Jumlah biaya tunai dan non tunai yang lebih tinggi pada kategori pengguna benih padi tidak bersubsidi mempengaruhi rendahnya pendapatan petani dibandingkan kategori petani lainnya. Hal ini dapat dilihat pada Tabel 5.

Perbedaan jumlah pengeluaran yang dikeluarkan oleh kedua kelompok petani berdampak pada perbedaan pendapatan yang diterima. Petani yang menggunakan benih padi bersubsidi menerima pendapatan yang lebih tinggi dari petani yang menggunakan benih padi tidak bersubsidi, baik pendapatan atas biaya tunai maupun pendapatan atas biaya total per ha pada setiap musim tanam. R/C ratio menggambarkan perbandingan penerimaan dan pengeluaran petani yang berdampak pada tingkat keuntungan kegiatan usahatani. Petani yang menggunakan benih padi bersubsidi memiliki penerimaan 2.18 kali lebih besar atas biaya tunai dan 2.02 kali lebih besar atas biaya total sedangkan petani yang tidak menggunakan benih padi bersubsidi memiliki penerimaan 1.55 kali lebih besar atas biaya tunai dan 1.40 kali lebih besar atas biaya total.

Berdasarkan perhitungan $\mathrm{R} / \mathrm{C}$ ratio tersebut kegiatan usahatani yang dilaksanakan oleh petani yang menggunakan benih padi bersubsidi memiliki keuntungan yang lebih besar dibandingkan petani yang tidak menggunakan benih padi bersubsidi, hal ini terdapat pada Tabel 5. 
Tabel 5. Rata-rata penerimaan, biaya, dan pendapatan usahatani berdasarkan penggunaan benih padi bersubsdi

\begin{tabular}{|c|c|c|c|c|c|}
\hline \multirow[b]{2}{*}{ No } & \multirow[b]{2}{*}{ Uraian } & \multicolumn{4}{|c|}{ Penggunaan Benih Padi } \\
\hline & & $\begin{array}{c}\text { Subsidi } \\
(\mathrm{Rp} / \mathrm{ha} / \mathrm{MT})\end{array}$ & $\begin{array}{c}\text { Persentase } \\
(\%)\end{array}$ & $\begin{array}{l}\text { Non Subsidi } \\
(\mathrm{Rp} / \mathrm{ha} / \mathrm{MT})\end{array}$ & $\begin{array}{c}\text { Persentase } \\
(\%)\end{array}$ \\
\hline 1 & Penerimaan & 26885007.00 & & 22660529.50 & \\
\hline 2 & Biaya Tunai & & & & \\
\hline & TKPLK & 1911360.00 & 14.36 & 4037800.00 & 25.01 \\
\hline & TKWLK & 1286880.00 & 9.67 & 2078750.00 & 12.88 \\
\hline & Benih & 120184.00 & 0.90 & 586065.00 & 3.63 \\
\hline & Pupuk Kompos & 759090.00 & 5.70 & 500004.00 & 3.10 \\
\hline & Pupuk Kandang & 400000.00 & 3.00 & 157500.89 & 0.98 \\
\hline & Pupuk Urea & 308743.50 & 2.32 & 1159785.26 & 7.18 \\
\hline & Pupuk TSP & 423949.99 & 3.18 & 541521.56 & 3.35 \\
\hline & Pupuk KCl & 345000.00 & 2.59 & 600000.00 & 3.72 \\
\hline & Pupuk Phonska & 522643.75 & 3.93 & 925650.00 & 5.73 \\
\hline & Pupuk NPK Kujang & 250000.00 & 1.88 & 0.00 & 0.00 \\
\hline & $\mathrm{PBB}$ & 381250.00 & 2.86 & 302333.00 & 1.87 \\
\hline & Pestisida Padat & 58950.46 & 0.44 & 0.00 & 0.00 \\
\hline & Pestisida Cair & 325557.79 & 2.45 & 93818.63 & 0.58 \\
\hline & Sewa Alat Olah Lahan & 200000.00 & 1.50 & 456250.00 & 2.83 \\
\hline & Sewa Lahan & 5000000.00 & 37.56 & 3000000.00 & 18.58 \\
\hline & Pengairan & 50000.00 & 0.38 & 150000.00 & 0.93 \\
\hline & Biaya Tunai & 12343609.49 & 92.72 & 14589478.34 & 90.37 \\
\hline 3 & Biaya Non Tunai & & & & \\
\hline & Biaya Penyusutan & & & & \\
\hline & Cangkul & 137483.20 & 1.03 & 82733.09 & 0.51 \\
\hline & Sabit & 23114.04 & 0.17 & 36377.14 & 0.23 \\
\hline & Garpu & 0.00 & 0.00 & 32500.00 & 0.20 \\
\hline & Sprayer & 124744.40 & 0.94 & 214285.50 & 1.33 \\
\hline & Total Penyusutan & 285341.64 & 2.14 & 365895.73 & 2.27 \\
\hline & TKPDK & 340641.80 & 2.56 & 585371.00 & 3.63 \\
\hline & TKWDK & 58000.00 & 0.44 & 237689.00 & 1.47 \\
\hline & Biaya Non Tunai & 969325.08 & 7.28 & 1554851.46 & 9.63 \\
\hline 4 & Biaya Total & 13312934.57 & 100.00 & 16144329.80 & 100.00 \\
\hline 5 & Pendapatan Atas Biaya & & & & \\
\hline & Tunai & 14541397.51 & & 8071051.16 & \\
\hline 6 & Pendapatan Atas Biaya & & & & \\
\hline & Total & 13572072.43 & & 6516199.70 & \\
\hline 7 & R/C Biaya Tunai & 2.18 & & 1.55 & \\
\hline 8 & R/C Biaya Total & 2.02 & & 1.40 & \\
\hline
\end{tabular}

Keterangan : Penerimaan $=($ jumlah output $*$ harga jual $)+$ pendapatan sampingan

\section{Fungsi Analisis Produksi}

Pendugaan fungsi faktor produksi gabungan antara petani yang menggunakan dan tidak menggunakan benih padi bersubsidi melalui model fungsi Cobb-Douglas. Faktor-faktor produksi yang digunakan untuk menunjukkan tingkat produksi padi $(\mathrm{Y})$, antara lain luas lahan $\left(\mathrm{X}_{1}\right)$, jumlah benih $\left(\mathrm{X}_{2}\right)$ yang digunakan pada satu musim tanam, jumlah penggunaan pupuk kompos $\left(\mathrm{X}_{3}\right)$ pada satu musim tanam, jumlah urea $\left(\mathrm{X}_{4}\right)$ yang digunakan pada satu musim tanam, jumlah pupuk TSP $\left(\mathrm{X}_{5}\right)$ yang digunakan dalam musim tanam, jumlah pupuk phonska $\left(\mathrm{X}_{6}\right)$ yang digunakan dalam satu musim tanam, jumlah penggunaan pupuk NPK kujang $\left(\mathrm{X}_{7}\right)$ dalam satu musim tanam, jumlah penggunaan tenaga kerja dibedakan menjadi tenaga kerja dalam keluarga $\left(\mathrm{X}_{8}\right)$ dan tenaga kerja luar keluarga $\left(\mathrm{X}_{9}\right)$, variabel dummy untuk petani yang menerima benih bersubsidi dan nol untuk petani yang tidak menggunakan benih bersubsidi $\left(D_{1}\right)$, variabel 
dummy untuk petani yang memiliki lahan dan nol untuk petani yang menyewa lahan $\left(\mathrm{D}_{2}\right)$ dalam menjalankan kegiatan usahatani, dan variabel dummy untuk petani yang menjadikan kegiatan usahatani padi sebagai pekerjaan utama dan nol untuk petani yang menjadikan pekerjaan sampingan $\left(D_{3}\right)$. Hasil pengolahan data menggunakan metode Ordinary Least Square (OLS) dengan mengestimasi data gabungan responden antara petani yang menggunakan benih padi bersubsidi dan benih padi tidak bersubsidi.

Hasil pengolahan data menghasilkan fhitung sebesar 0.00 lebih kecil dari $\alpha 10$ persen. Hal ini membuktikan bahwa variabel bebas yang diwakili oleh luas lahan, benih, pupuk kompos, pupuk urea, pupuk TSP, pupuk phonska, pupuk NPK kujang, tenaga kerja dalam keluarga, tenaga kerja luar keluarga, penggunaan benih padi bersubsidi, status kepemilikan lahan, dan status pekerjaan usahatani berpengaruh nyata terhadap variabel tidak bebas (produksi) pada taraf 10 persen. Pengolahan data menghasilkan nilai R-sq sebesar 90 persen, hal ini menunjukkan bahwa 90 persen variabel bebas dapat menjelaskan variabel tidak bebas pada taraf 10 persen, sedangkan 10 persen lainnya dijelaskan oleh faktor lain di luar model. Hal ini ditunjukkan pada Tabel 6.

Tabel 6. Hasil pendugaan fungsi produksi usahatani padi

\begin{tabular}{|c|c|c|c|c|c|}
\hline Input Produksi & Koefisien & Standar Error & t-hitung & $\mathrm{P}$ & VIF \\
\hline Konstanta & 7.19517 & 0.47264 & 15.22336 & 0.00000 & \\
\hline Luas lahan $\left(\mathrm{X}_{1}\right)$ & 0.87261 & 0.23277 & 3.74882 & $0.00090 *$ & 2.88 \\
\hline $\operatorname{Benih}\left(\mathrm{X}_{2}\right)$ & 0.00437 & 0.00488 & 0.89595 & 0.37820 & 3.14 \\
\hline Pupuk kompos $\left(\mathrm{X}_{3}\right)$ & 0.00012 & 0.00005 & 2.42355 & $0.02230 *$ & 1.74 \\
\hline Pupuk urea $\left(\mathrm{X}_{4}\right)$ & -0.00075 & 0.00056 & -1.33065 & 0.19440 & 4.42 \\
\hline Pupuk TSP $\left(\mathrm{X}_{5}\right)$ & 0.00164 & 0.00082 & 2.01392 & $0.05410 *$ & 2.59 \\
\hline Pupuk phonska $\left(\mathrm{X}_{6}\right)$ & 0.00018 & 0.00051 & 0.36232 & 0.71990 & 1.64 \\
\hline Pupk NPK & 0.00136 & 0.00290 & 0.46745 & 0.64390 & 1.46 \\
\hline kujang $\left(\mathrm{X}_{7}\right)$ & & & & & \\
\hline $\begin{array}{l}\text { Tenaga kerja } \\
\text { dalam keluarga }\left(\mathrm{X}_{8}\right)\end{array}$ & -0.00849 & 0.00189 & -4.49410 & $0.00010 *$ & 1.75 \\
\hline $\begin{array}{l}\text { Tenaga kerja } \\
\text { luar keluarga }\left(\mathrm{X}_{9}\right)\end{array}$ & -0.00018 & 0.00073 & -0.24509 & 0.80820 & 1.45 \\
\hline $\begin{array}{l}\text { Penggunaan Benih } \\
\left(D_{1}\right)\end{array}$ & 0.44833 & 0.24016 & 1.86681 & $0.07280 *$ & 3.61 \\
\hline $\begin{array}{l}\text { Kepemilikan lahan } \\
\left(\mathrm{D}_{2}\right)\end{array}$ & -0.43310 & 0.19860 & -2.18077 & $0.03810 *$ & 1.85 \\
\hline $\begin{array}{l}\text { Status Pekerjaan } \\
\text { Usahatani }\left(\mathrm{D}_{3}\right)\end{array}$ & 0.02298 & 0.26289 & 008743 & 0.93100 & 1.56 \\
\hline R-squared & 0.90 & \multicolumn{2}{|c|}{ Durbin-Watson stat } & 2.18 & \\
\hline Adjusted R-squared & 0.86 & \multirow{2}{*}{\multicolumn{2}{|c|}{ Prob(F-statistic) }} & 0.00 & \\
\hline F-statistic & 20.69 & & & & \\
\hline
\end{tabular}

Keterangan: *= nyata terhadap $\alpha 10 \%$

Pendugaan model fungsi produksi padi dengan menggunakan model Cobb-Douglas dapat dijabarkan sebagai berikut:

$\mathrm{Ln} \mathrm{Y}=7.19517+0.87261 \operatorname{Ln} \mathrm{X}_{1}+0.00437 \mathrm{Ln}$ $\mathrm{X}_{2}+0.00012 \operatorname{Ln~} \mathrm{X}_{3}-0.00075 \operatorname{Ln~} \mathrm{X}_{4}+0.00164$ Ln $X_{5}+0.00018$ Ln $X_{6}+0.00136$ Ln $X_{7}-$ $0.00849 \operatorname{Ln} \mathrm{X}_{8}-0.00018 \mathrm{Ln} \mathrm{X}_{9}+0.44833 \mathrm{D}_{1}-$ $0.43310 \mathrm{D}_{2}+0.02298 \mathrm{D}_{3}$.

\section{KESIMPULAN}

Penggunaan input produksi berupa pupuk organik, benih bermutu, dan pestisida pada petani pengguna benih padi bersubsidi lebih tinggi dibandingkan kategori petani lainnya, namun lebih rendah dalam penggunaan pupuk kimia. Produksi output petani yang menggunakan benih padi bersubsidi lebih tinggi dibandingkan petani yang menggunakan benih padi tidak bersubsidi, serta nilai $\mathrm{R} / \mathrm{C}$ ratio menunjukkan bahwa petani yang menggunakan benih padi bersubsidi memiliki tingkat pendapatan yang lebih tinggi dibandingkan petani yang menggunakan benih padi tidak bersubsidi. 


\section{DAFTAR PUSTAKA}

[BPS] Badan Pusat Statistik. 2015. Produksi padi tahun 2014 (angka sementara) diperkirakan turun 0.63 persen. http://www.bps.go.id [13 Oktober 2015].

[BPTP Kaltim] Balai Pengkajian Teknologi Pertanian Kalimantan Timur. 2011. Pemanfaatan limbah pertanian (jerami padi) sebagai bahan organik dengan menggunakan tricholant. http://kaltim.litbang.pertanian.go.id [28 Juni 2016].

Data Monografi. 2015. Data monografi desa Ciherang, kecamatan Dramaga, Kabupaten Bogor.

Ellis, F. 1992. Agricultural Policies in Developing Countries. Cambridge(UK): Cambridge University Press.

[IRRI] International Rice Research Institute. 2001. Dampak dan Kedepan: Sekilas Kerjasama Indonesia. IRRI, Jakarta, Indonesia.

Kariyasa, K. 2007. Usulan pola kebijakan pemberian dan pendistribusian benih padi bersubsidi. Analisis Kebijakan Pertanian. 5(4): 304-319.

Mahmud, Y., Nurlenawati, N., Sugiarto. 2010. Pengaruh macam perlakuan benih terhadap pertumbuhan dan hasil beberapa varietas unggul baru tanaman padi (Oryza sativa L.) di lahan sawah irigasi kecamatan tempuran kabupaten Karawang. Solusi. 9(17): 53-63.
Profil Desa, 2015. Profil terbaru desa Cibitung Tengah, kecamatan Tenjolaya, Kabupaten Bogor.

[Puslitbang Tanaman Pangan] Pusat Pengembangan dan Penelitian Tanaman Pangan. 2014. Produksi padi menuju 2020. http://pangan.litbang.pertanian.go.id [13 Oktober 2015].

Rachman, B., Simatupang, P., Sudaryanto, T. 2004. Efisiensi dan daya saing sistem usahatani padi. http://pse.litbang.pertanian.go.id [13 September 2015].

Riyanto, W., Ridwansyah, M., Umiyati, E. 2013. Permintaan beras di provinsi Jambi (penetapan partial adjustment model). Jur.Perspektif Pembiayaan dan Pembangunan Daerah. 1(1): 11-20.

Rosmarkam, A., Yuwono, N.W. 2002. Ilmu Kesuburan Tanah. Yogyakarta(ID): Kanisius.

Stevens, G., Hefner, S., Tanner, E. 1999. Monitoring crop nitrogen in rice using portable chlorophyll meters. Missouri Rice from 1997-98. University of Missouri, Delta Center, US.

Wahid, A.S. 2003. Peningkatan efisiensi pupuk nitrogen pada padi sawah dengan metode bagan warna daun. Jur. Lit. Pertanian. 22(4): 156-161.

Widiarsih, D. 2013. Pengaruh Sektor Komoditi Beras Terhadap Inflasi Bahan Makanan. http://ejournal.unri.ac.id [30 September 2015]. 